ment Apocrypha, and the Apostolic Fathers. He gives the Hebrew word which the LXX word translates. All this is carefully done and the book is compact and handy. But when all is said, one must admit that we do not get a full rounded view of the New Testament rocabulary by this method. But, while one may criticize the method, Preuschen has wrought. ably along his chosen path and the book will be eagerly sought by New Testament students who wish to get the benefit of Preuschen's valuable researches.

A. T. Roberison.

\title{
III. THEOLOGY.
}

\section{Salvation in the Old Theology.}

By Rev. Len. G. Broughton, D. D. The Fleming H. Revell Company. Cloth. Pp. 88. Price 75 cents, net.

The books consists of Bible School talks carefully revised for publication. They deal with pivotal points in the Epistle to the Romans.

Judged by scholastic standards, these talks can claim no special merit. The analysis, whilst often illuminating, lacks in perspective, gives an impression of scrappiness, and some. times is out of line with the Apostle's thought. An instance is seen in Chapter $X$., which deals with Rom. 6:15-23. The title of that chapter, "Relation of Salvation to Law," raises to the chief place a thought which in that passage is incidental. Pau!'s discussion of the relation of salvation to law is found in Rom. 7:7-25. It is true the thought underlies much that has gone before but in the earlier chapters it fnds only incidental expression.

So the real meaning of words and phrases is sometimes missed. The idea that $\sigma$ áp than rapkikós is neither in keeping with the meaning of the word nor suitable to the context. The latter is literally applicable to the worldly-minded Christian; the former can only be applied to a Christian in a sort of figurative way as by Paul in 1 Cor. $3: 1$. There the idea is that just as a new born child may be spoken of as a mere mass of flesh with no human ability to reason or speak, so Paul feels that they are as ( $\dot{\omega} s)$ mere flesh and incapable of understanding any spiritual word 
he might say to them. In the third verse of the same chapter he reverts to the more natural word oapricol now without any is since it represents the exact fact.

Equally astray is the author when he translates $\nu_{0} c^{\prime}(7: 25)$ by "heart" and when he refers $8: 11$, "Shall quicken your mortal bodies," to present experience rather than to the future resurrection of the body.

But these are but flies in precious ointment. Dr. Broughton possesses fine spiritual insight and expounds the doctrines of grace with great freshness and power. Chapter IX, in "The Relation of Salvation to Life" is worth the price of the book. Equally happy is the treatment of justification, sanctification, the function of the law and the work of the Spirit. His illustrations are simple, clear, graphic, and very apt. With their racy style and crisp sentences the talks read well. It must have been delightful and stimulating to listen to them, clothed with the power and authority which Dr. Broughton's fine personality must have given them. J. H. FARMER.

\section{"How Does the Death of Christ Save Us?" \\ By Henry C. Mabie, D. D. American Baptist Pub. Society, Phila- delphia.}

Those that know Dr. Mabie know what to expect of him on this subject, "The Atonement." He has given us a reverent ond humble and fearless treatment of the subject. According to his view, the sacrificial death of Christ embraces all that is meant by Salvation - the forgiveness of sins, grace for holy living, spiritual power for service. Christ did not die as a good man, to set us an example of patient suffering for others. He could not so die; for he was and is the Son of God. He vcluntarily took the place of sinful men, knew what he had to suffer and what he would accomplish through his death. His death was more than physical. So far as his enemies were concerned, he was murdered. But on the divine side he offered himself as a sacrifice for sin. His death involves the resurrection and the ascension, and divine enduement of power, and implies a vital union with Christ, and the renewal 